\title{
Microscopic Characterization of Au Nanoparticles Prepared by Sputtering Method
}

\author{
Alena Michalcová, Dalibor Vojtěch \\ Department of Metals and Corrosion Engineering, University of chemistry and technology, Technicka 5, Prague 6, 16628, \\ Czech Republic. E-mail: michalca@vscht.cz, vojtechd@vscht.cz
}

This article offers a novel method of gold nanoparticles preparation which increases their obsevation feasibility. Gold nanoparticles were prepared by sputtering of $6 \mathrm{~nm}$ of gold on surface of $\mathrm{NaCl}$ crystals and consequent annealing. Gold nanoparticles were separated from the substrate mechanically in the ultrasonic bath. The preparation of gold nanoparticles on $\mathrm{NaCl}$ substate is extremely versatile. It enables to descibe size and shape of the individual nanoparticles much better than usually used SEM and AFM techniques, it enables to see the lattice arrangements and also to do more precise chemical analysis without the influence of the substrate. It is applicable for characterization of temperature-, time-, chemical composition- and atmosphere influence on morphology of gold nanoparticles. The nanoparticles were observed by HRTEM. In our case, the influence of carbon addition on morphology of gold nanoparticles was studied by sputtering one or two carbon interlayes in the gold layer. It was found out that one carbon interlayer slightly descrease nanoparticle size. On the other hand, two carbon interlayers lead to formation of irregular large shapes of the gold particles.

Keywords: TEM, nanoparticles, sputtering

\section{Acknowledgement}

This work was financially supported by Czech Science Foundation (project No. P108/12/G043).

\section{References}

[1] VOJTECH, D., MICHALCOVA, A., KNOTEK, V., MAREK, I. (2012). Study of nano-crystalline metals prepared by selective chemical leaching. In: Manufacturing Technology, Vol. 12, No. 13, pp. 292-296. Faculty of Production Technology and Management. CR.

[2] MAREK, I., MICHALCOVA, A., VOJTECH, D. (2013). Properties of metallic nanocrystalline powders. In: Manufacturing Technology, Vol. 13, No. 3, pp. 353-358. Faculty of Production Technology and Management. CR.

[3] MiCHAlCOVA, A., VOJTECH, D., MAREK, I., SVOBODOVA, P., NOVAKOVA, R. (2013). Preparation of Metallic Nanoparticles. In: Manufacturing Technology, Vol. 13, No. 3, pp. 353-358. Faculty of Production Technology and Management. CR.

[4] SUN, X., LI, H. (2013). Gold nanoisland arrays by repeated deposition and post-deposition annealing for surfaceenhanced Raman Spectroscopy. In: Nanotechnology, Vol. 24, pp. 1-9. IOP Publishing. UK.

[5] STELZNER, T., ANDRA, G., WENDLER, E., WESCH, W., SCHOLZ, R., GOSELE, U., CHRISTIANSEN, S. (2006). Growth of silicon nanowires by chemical vapour deposition on gold implanted silicon substrates. In: $\mathrm{Na}$ notechnology, Vol. 17, pp. 2895-2898. IOP Publishing. UK.

[6] LI, C. P., SUN, X. H., WONG, N. B., LEE, C. S., LEE, S. T., TEO, B.K. (2002). Silicon Nanowires Wrapped with Au Film. J. Phys. Chem. B, Vol. 106, pp. 6980-6984. American Chemical Society. USA.

[7] BECHELANY, M., MAEDER, X., RIESTERER, J., HANKACHE, J., LEROSE, D., CHRISTIANSEN, S., MICHLER, J., PHILIPPE, L. (2009). Synthesis Mechanisms of Organized Gold Nanoparticles: Influence of Annealing Temperature and Atmosphere. In: Crystal Growth \& Design, Vol. 10, No. 2, pp. 587-596. American Chemical Society. USA.

[8] LEE, J., PANDEY, P., SUI, M., LI, M., ZHANG, Q., KUNWAR, S. (2015). Evolution of Self-Assembled Au NPs by Controlling Annealing Temperature and Dwelling Time on Sapphire (0001). Nanoscale Research Letters, Vol. 10, No. 424, pp. 1-11. Springer. Germany.

[9] LI, B., HUANG, L., ZHOU, M., FAN, X., MA, M. (2014). Preparation and Spectral Analysis of Gold Nanoparticles Using Magnetron Sputtering and Thermal Annealing. Journal of Wuhan University of Technology-Mater. Sci. Ed., Vol.29, No.4, pp. 651-655. Wuhan University. China.

[10] BELAHMAR, A., CHOUIYAKH, A., (2016). Sputtering synthesis and thermal annealing effect on gold nanoparticles in Al2O3 matrix. J. Nanosci. Tech. Vol. 2, No. 2, pp.100-103. . American Chemical Society. USA. 
[11] CHAN, K., GOH, B.T., RAHMAN, S.A., MUHAMAD, M.R., DEE, CH. F., ASPANUT, Z. (2012). Annealing effect on the structural and optical properties of embedded Au nanoparticles in silicon suboxide films. Vacuum, Vol. 86, pp. 1367-1372. Elsevier B.V. The Netherlands.

[12] SIEGEL, J., KRAJCAR, R., KOLSKÁ, Z., HNATOWICZ, V., ŠVORČÍK, V. (2011). Annealing of gold nanostructures sputtered on Polytetrafluoroethylene. Nanoscale Research Letters, Vol. 6, No. 588, pp. 1-6. Springer. Germany.

[13] SIEGEL, J., LYUTAKOV, O., RYBKA, V., KOLSKÁ, Z., ŠVORČÍIK, V. (2011). Properties of gold nanostructures sputtered on glass. Nanoscale Research Letters, Vol. 6, No. 96, pp. 1-9. Springer. Germany.

[14] Chen, T., Zhang, Z., Chen, H.Y., Wu, T. (2008). Tailoring the photoluminescence of ZnO nanowires using Au nanoparticles. In: Nanotechnology, Vol. 19, pp. 1-6. IOP Publishing. UK.

Paper number: M2016193

Copyright $\odot$ 2016. Published by Manufacturing Technology. All rights reserved. 